\title{
Dari Desentralisasi Jaringan ke [De]sentralisasi Kuasa: Dinamika, Kekuatan dan Pukulan Balik
}

\author{
Rendy Pahrun Wadipalapa \\ Universitas Airlangga
}

\begin{abstract}
Abstrak
Kuasa bekerja dalam jaringan di mana di dalamnya tiap aktor selalu dalam posisi menjalankan dan dijalankan kekuasaan. Kuasa tidak bisa dimiliki, tetapi disirkulasikan, saling didiseminasikan, dan dipertukarkan dalam sebaran jejaring yang luas. Masingmasing aktor menginginkan tetap dalam sirkulasi antar dan intra jaringan sehingga mampu mengikuti arusnya untuk bisa bertahan. Upaya desentralisasi jaringan telah mengubah keseimbangan kekuasaan politik. Namun demikian, bentuk teknologi komunikasi jaringan sosial saat ini, meskipun memiliki nilai yang sangat besar untuk dimanfaatkan sebagai kekuatan dan konsolidasi politik, juga sangat berisiko mengalami pukulan balik. Sistem desentralisasi yang ada saat ini, dalam beberapa hal memiliki celah dan terpusat, dalam beberapa aspek masih tampak sentralistis. Mereka terlalu rentan terhadap pembalasan dan kontrol negara.
\end{abstract}

Kata kunci : kuasa, desentralisasi, jaringan

\begin{abstract}
Power works in a network where each actor in it is always in a position of power to run and run. Power can not be owned, but circulated, disseminated each other, and exchanged in a wide distribution network. Each of these actors want to remain in the circulation of inter-and intra network so as to follow the current is to survive. Decentralization efforts the network has changed the balance of political power. However, forms of social network communication technology today, although it has tremendous value to be used as power and political consolidation, also risk a backlash. Decentralized system that exists today, in some ways has a crack and centralized, in some aspects still looks centralized: they are too vulnerable to state retaliation and control.
\end{abstract}

Keyword : power, decentralization, networking

Pendahuluan : Mode Jaringan Awal

"Kekuasaan ada di mana-mana, suatu jaringan subtil dari wacana, pengetahuan, kenikmatan, dan kekuasaan" (Foucault, 1976).

"Saya mengikuti kegaduhan di jaringan 'social media'" (Susilo Bambang Yudhoyono, 2012)

Yudhoyono dan Foucault tentu tidak sedang berdiskusi atas apa itu filosofi jaringan, tetapi pernyataan keduanya saling berkait satu sama lain: mereka sama-sama bicara atas tema kekuasaan. Yang pertama datang dari pikiran filosof kekuasaan; sementara yang kedua lahir dari statemen penguasa.

Bagi Michel Foucault, kekuasaan bekerja dalam jaringan di mana di dalamnya tiap aktor selalu dalam posisi menjalankan dan dijalankan kekuasaan. Kekuasaan tidak bisa dimiliki, tetapi disirkulasikan, saling didiseminasikan, dan dipertukarkan dalam sebaran 
jejaring yang luas. Masing-masing aktor menginginkan tetap dalam sirkulasi antar dan intra jaringan sehingga mampu mengikuti arusnya untuk bisa bertahan. Pada beberapa tahap, jaringan itu mengalami akselerasi ke dalam bentuknya yang baru, yang diilhami oleh teknologi berlandas komputer. Ia terdesentralisasi.

Dan persis di sinilah posisi kegelisahan Yudhoyono bertempat: jaringan baru ini terlampau gaduh. Sebelum ingar-bingar jejaring sosial media baru (new media) meruap, konsepsi tentang apa itu jaringan dalam ranah komunikasi telah lama bertumbuh. Inter-koneksi antar pribadi yang satu dengan yang lain, menjadi asumsi utama apa dan bagaimana jaringan sosial pada awalnya dipahami. Tulisan ini akan melihat bagaimana jaringan itu dikonseptualisasikan dalam banyak tradisi keilmuan komunikasi, serta bagaimana ia diartikulasikan secara bertahap. Kedua hal ini pada gilirannya akan meringkas pertanyaan besar yang banyak diajukan sebagai dilema teknologi komunikasi kontemporer: apa implikasi sosio-politis atas jejaring komunikasi?

Perkembangan analisis jaringan komunikasi itu sendiri diringkas sebagai perjalanan awal dari tiga model. Pertama, model komunikasi linear. Kedua, kritik terhadap model komunikasi linear. Ketiga, model komunikasi konvergensi.

$$
\text { Model komunikasi linier }
$$
dikembangkan oleh Shannon dan Weaver (1949) melalui bukunya: The Mathematical Theory of Communication. Bagi tradisi linier ini, konsepsi jaringan komunikasi belum dikenal oleh karena komunikasi dipandang sebagai aktifitas penyampaian informasi dari sumber kepada komunikan lewat aliran satu arah (dari komunikator ke komunikan). Kritik paling keras terhadap model linear ini, yang lantas menjadi muasal konsepsi atas jaringan komunikasi, terutama berisi pandangan kritis bahwa dalam setiap komunikasi, komunikator dan komunikan adalah dua pihak yang aktif, dan melakukan transaksi informasi untuk tujuan pengertian bersama. Kesamaan pada satu tujuan bersama ini disebut konvergensi. Ada satu wilayah 'tumpang-tindih' antara komunikator dan komunikan dalam proses komunikasi atau penggunaan informasi bersama. Konvergensi antara satu orang dengan orang lain tidak pernah lengkap dan sempurna, dan di sanalah terjadinya proses konvergensi yang bersifat dinamis. Di sini, jaringan komunikasi antar individu diperhatikan sebagai salah satu variabel penting.

Analisis jaringan komunikasi tumbuh menjadi salah satu pendekatan dari penelitian yang mempelajari perilaku manusia berdasarkan pendekatan model konvergen. Rogers dan Kincaid (1981) menegaskan bahwa analisis jaringan komunikasi merupakan metode penelitian untuk mengidentifikasi struktur komunikasi dalam suatu sistem, di mana data hubungan mengenai arus komunikasi dianalisis dengan menggunakan beberapa tipe hubungan interpersonal sebagai unit analisis. Lebih lanjut salah satu tujuan penelitian komunikasi dengan menggunakan analisis jaringan komunikasi adalah untuk memahami gambaran umum mengenai interaksi manusia dalam suatu sistem.

Logika jaringan yang dipaparkan teoretisi awal jaringan semisal Rogers ini, penting guna membangun pemahaman paling dasar, sebelum berangkat dalam diskusi desentralisasi jaringan. Struktur komunikasi adalah susunan dari unsur-unsur komunikasi yang berbeda 
yang dapat dikenali melalui pola arus komunikasi dalam suatu sistem (Rogers \& Kincaid 1981). Hal yang dapat dilakukan dalam analisis jaringan komunikasi, yaitu: (1) mengidentifikasi klik dalam suatu sistem; (2) mengidentifikasi peranan khusus seseorang dalam jaringan misalnya sebagai liaisons, bridges, dan isolated; dan (3) mengukur berbagai indikator (indeks) struktur komunikasi seperti keterhubungan Klik, keterbukaan klik, keintegrasian klik, dan lain sebagainya. Sementara itu yang dimaksud dengan klik adalah bagian dari sistem (sub sistem) di mana anggota-anggotanya relatif lebih sering berinteraksi satu sama lain dibandingkan dengan anggota-anggota lainnya dalam sistem komunikasi (Rogers \& Kincaid, 1981).

Sebagai dasar untuk mengetahui apakah individu-individu itu dapat dimasukkan ke dalam suatu klik atau tidak, ada tiga kriteria yang dapat digunakan untuk mengidentifikasi klik, yaitu: (1) setiap klik minimal harus terdiri dari tiga anggota; (2) setiap anggota klik minimal harus mempunyai derajat keterhubungan 50\% dari hubunganhubungannya di dalam klik; dan (3) seluruh anggota klik baik secara langsung maupun tidak langsung harus saling berhubungan melalui suatu rantai hubungan dyadic yang berlangsung secara kontinyu dan menyeluruh di dalam klik (Rogers \& Kincaid 1981).

Proses komunikasi yang terjadi dalam jaringan komunikasi dapat dijelaskan dengan menggunakan model konvergen sebagai berikut (Berlo, 1960; Rogers dan Kincaid, 1981) : 1. Satu informasi bisa mengandung beberapa pengertian tergantung pada konteksnya, dan untuk mengambil pengertian tergantung pada "frame of reference". 2. Terciptanya kesamaan makna akan suatu informasi antara komunikator dan komunikan merupakan tujuan utama berkomunikasi. 3. Hubungan interaktif antara komunikator dengan komunikan menggunakan saluran jaringan komunikasi yaitu saluran untuk menyampaikan pesan dari satu orang ke oran lain 4. Dari hal-hal di atas dapat disimpulkan bahwa proses komunikasi akan terjadi bila ada kesamaan pengertian terhadap informasi dari pelaku-pelaku yang berkomunikasi dengan menggunakan jaringan komunikasi yang menghubungkan individu dengan individu atau individu dengam kelompok.

Pada konteks komunikasi, adalah konvergensi yang memungkinkan integrasi progresif dari beberapa platform jaringan yang berbeda untuk menyalurkan layanan yang serupa dan atau layanan-layanan yang berbeda yang disalurkan pada platform jaringan yang sama.

Sampai sini, maka konvergensi mendasari desentralisasi, yang semakin intens beriringan dengan kehadiran situs jejaring sosial di ruang maya. Desentralisasi memanfaatkan konvergensi untuk mendistribusikan keleluasaan yang lebih bebas bagi user, baik sebagai produsen teks/pesan, distributor, maupun konsumen itu sendiri-penjelasan secara teknis akan dielaborasi lebih lanjut pada bagian berikutnya. Yang penting diketahui adalah, menguatnya ide desentralisasi jaringan dipicu oleh luasnya akses internet, lebih-lebih dari terciptanya beragam situs jejaring sosial yang memberi keleluasaan besar bagi user (Ahn, et. al.: 2011)

Sekilas pandang tentang apa dan bagaimana situs-situs ini berkembang 
adalah sesuatu yang penting untuk menjelaskan titik berangkat. Situs jejaring sosial pertama, yaitu sixdegrees.com mulai muncul pada tahun 1997. Situs ini memiliki aplikasi untuk membuat profil, menambah teman, dan mengirim pesan. Tahun 1999 dan 2000, muncul situs sosial lunarstorm, live journal, cyword yang berfungsi memperluas informasi secara searah. Tahun 2001, muncul ryze.com yang berperan untuk memperbesar jejaring bisnis. Tahun 2002, muncul friendster sebagai situs anak muda pertama yang semula disediakan untuk tempat pencarian jodoh, namun dalam kelanjutannya, jejaring ini lebih diminati anak muda untuk untuk saling berkenalan dengan pengguna lain. Tahun 2003, muncul situs sosial interaktif lain menyusul kemunculan friendster, Flick $R$, You Tube, Myspace.

Memasuki tahun 2006, penggunaan friendster dan Myspace mulai tergeser dengan adanya facebook. Facebook dengan tampilan yang lebih modern memungkinkan orang untuk berkenalan dan mengakses informasi seluas-luasnya. Tahun 2009, kemunculan Twitter ternyata menambah jumlah situs sosial. Twitter menggunakan sistem mengikuti-tidak mengikuti (follow-unfollow), dimana kita dapat melihat status terbaru dari orang yang kita ikuti (follow). Kemudian pada tahun ini muncul jejaring sosial baru yaitu youfriends.net lebih memungkinkan fitur-fitur yang belum ada pada jejaring lainnya seperti photo editor, zodiak, ramalan, halaman, game lebih banyak.

\section{Desentralisasi: Teknis \& Politis}

Pada bagian ini, akan didedah dua pandangan mengenai desentralisasi, dari penjelasan peristiwa yang sangat teknis, hingga kontekstualisasi konsep desentralisasi dalam ranah Indonesia secara politis.

Secara teknis, model teknologi jaringan yang terdesentralisasi adalah model di mana suatu keahlian teknis dari produksi dan konsumsi pesan sepenuhnya didistribusikan secara swakelola kepada masing-masing individu ahli. Dalam model teknologi dengan logika seperti ini, maka seluruh sistem komunikasi didesain menjadi sistem multi-agent dimana siapapun tidak dibatasi dalam menciptakan perangkat lunak, memroduksi pesan, mengelola lalu-lintas pesan, dan sebagainya.

Sementara sistem teknologi sentralistis lebih rentan terhadap fluktuasi, kurang mampu beradaptasi dengan perubahan situasional, dan sering membutuhkan investasi modal besar untuk menyediakan infrastruktur pendukungnya, sistem desentralisasi cenderung lebih fleksibel, mampu beradaptasi, dan dapat mengambil keuntungan dari produksi dan penggunaan media teknologi secara massal sekaligus murah dan mudah diakses. Alasan-alasan teknis ini membuat sistem desentralisasi jaringan beroperasi secara lebih efisien (Barabasi \& Reka: 1999).

AdalahPaulBaran(1964)yangmenilai bahwa efisiensi sistem desentralisasi komunikasi harus diberi tempat pada perkembangan teknologi mutakhir. Baran menciptakan sebuah taksonomi untuk menggambarkan berbagai jenis sistem, dari yang terdistribusi, terdesentralisasi, dan terpusat. Periksa gambar berikut: 


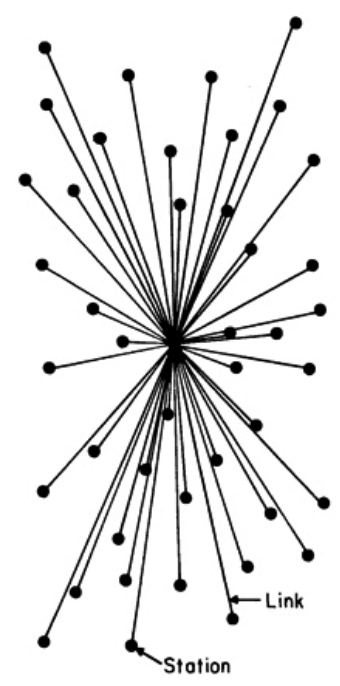

CENTRALIZED (A)

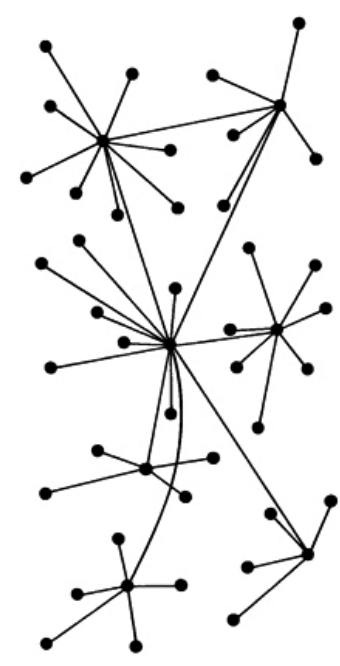

DECENTRALIZED

(B)

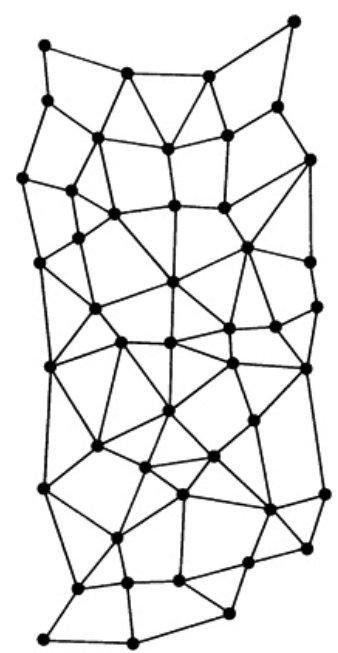

DISTRIBUTED

(C)

FIG. I - Centralized, Decentralized and Distributed Networks

Dari tiga model ini, secara teknis, model desentralisasi komunikasi jauh lebih menguntungkan ketimbang sistem dengan logika sentralistis. Paling tidak ada empat alasan fundamental mengapa sistem teknologi sentralistis bermasalah. Pertama, sistem tersentral seringkali menimbun informasi. Ia tidak mampu memberi daya untuk melakukan pembagian informasi dan pesan, sehingga itu berarti pula ia membatasi akses informasi. Kedua, sistem tersentral membatasi pengambilan keputusan dan kemandirian dalam berimprovisasi. Operator komunikasi terpusat secara oligarkis, sehingga titik kendali pesan dibatasi. Ketiga, ketakutan pada risiko kegagalan teknis. Sistem tersentral mengandalkan asumsi utama bahwa sistem adalah pusat komunikasi, ia harus dikelola pula secara terpusat. Membagi pengelolaan dan produksi pesan/ informasi hanya akan menciptakan peluang kegagalan/kerusakan teknis. Keempat, miskin inovasi. Sentralisme komunikasi tidak menciptakan kebaruan, atau sekalipun ada, kebaruan itu bergerak lambat dan lama (Baran: 1964).

Akan tetapi, secara teknis pula, sistem terdesentralisasi mengalami kelemahan, terutama dari risiko besar kegagalan server dalam mengendalikan anarki pesan, karena tiap individu atau user diberi kesempatan yang sama dalam berpartisipasi. Kini, dapat dibayangkan bagaimana protokol didistribusikan lewat server yang berbeda sebagai suatu simpul, dan dijalankan oleh perusahaan hosting yang berbeda, dan pada masingmasing simpul ini dapat digunakan untuk menyimpan banyak account.

Konsepsi desentralisasi jaringan tidak mungkin dijelaskan tanpa melakukan tarikan historis atas kemunculan jaringan, dan bagaimana ia didesentralisasikan. Sejak kemunculan teknologi komputer pertama kali pada awal dekade 50 untuk sensus data di Amerika Serikat, kemunculan jaringan baru terjadi ketika project ARPANET (Advanced Research Projects Agency Network) diluncurkan pada tahun 1960. Program ini ditujukan untuk sebuah eksperimen dan demonstrasi desentralisasi jaringan komputer yang akhirnya berkembang menjadi struktur dari internet. Tujuan awalnya: memperbaharui alat pertahanan untuk menghadapi musuh yang bisa 
mengancam untuk menyerang jaringan yang terpusat (Goldsmith \& Wu: 2006).

Titik perkembangan selanjutnya adalah dimunculkannya P2P (Peer-toPeer) yang pertama kali diluncurkan dan dipopulerkan oleh aplikasi-aplikasi "berbagi-berkas" (file sharing) seperti Napster. Pada konteks ini teknologi P2P memungkinkan para pengguna untuk berbagi, mencari dan mengunduh berkas (Poplawski: 2008). Sistem ini memungkinkan satu komputer dengan komputer lain untuk saling berhubungan secara dinamis dan berpartisipasi dalam mengarahkan lalu lintas komunikasi informasi, pemrosesan, dan pembagian bandwidth yang intensif, dimana bila sistem ini tidak ada, tugas-tugas ini biasanya diemban oleh server pusat (Donath dan Boyd, 2004).

Tumbuh-kembang jaringan peerto-peer meluas ketika Microsoft merilis sistem operasi Windows for Workgroups. Karakteristik kunci jaringan tersebut adalah dalam jaringan ini tidak terdapat sebuah server pusat yang mengatur klienklien, karena memang setiap komputer bertindak sebagai server untuk komputer klien lainnya. Sistem keamanan yang ditawarkan oleh metode ini terbilang lebih rendah dibandingkan dengan metode klien/server dan manajemen terhadapnya pun menjadi relatif lebih rumit (Morland, 2005).

Di samping penjelasan teknis, penulis berupaya menerangkan hal-ihwal desentralisasi dari perspektif politis dalam konteks Indonesia. Sekurangkurangnya, ada dua ragam desentralisasi dari sudut pandang politis, di mana keduanya menyusun dirinya berdasarkan urutan waktu dan bertambah rumitnya teknologi. Pada lapis pertama, desentralisasi jaringan menerpa dan hanya berhenti pada perkara institusi media. Orde Lama dan Orde Baru menerapkan logika monolitik atas tata-kelola media, dengan cara menempatkan TVRI sebagai satu-satunya media yang diakui dan diturut, sementara tumbuhnya media lain hanya boleh menawarkan sesuatu yang sifatnya periferal, tepian, dengan tetap menghormati negara dan medianya, TVRI, sebagai sentral. Upaya pembaharuan politik pada 1998 membawa serta dekonstruksi atas sentralisasi. Kekuasaan negara dipreteli, termasuk dalam ranah media. Pembentukan institusi media menjadi luwes dan menafikan semua peraturan represif: SIT, SIUPP, dan sebagainya.

Namun demikian, pada lapis pertama ini, desentralisasi kuasa media berhenti pada level institusional. Artinya, kuasa hanya turun dan dibagi pada lembaga-per-lembaga, bukan individu-per-individu. Sentralistis TVRI dibagi ke stasiun/institusi media lain semisal RCTI, SCTV, dan sejenisnya. Barulah pada lapis kedua, dipicu oleh gelombang besar revolusi media baru dan rekontekstualisasi media berjejaring sosial, desentralisasi kuasa tiba sampai pada tataran individu. Teknologi dengan basis media komputer, membawa konsekuensi meningkatnya hubungan antara individu dan media, sekaligus membebaskan batasan siapa produsen dan siapa konsumen.

Desentralisasi jaringan juga berada pada konteks yang melingkungi transformasi masyarakat dari analog ke digital. Itu berarti terjadi pula metamorfosa atas transmisi informasi, yang secara radikal berubah menjadi pertukaran informasi yang bebas, yang hampir memberikan dilema atas privasi, kekayaan intelektual, dan sebagainya (Cardoso,2006). Distribusi informasi yang dimengerti secara konvensional, terlepas dari konteks desentralisasi jaringan, adalah hasil adopsi dari pencetakan yang 
bermula di akhir abad kelima belas dan terus berkembang sampai akhir abad dua puluh. Informasi dipahami sebagaiartefak fisik, dimana memerlukan persyaratan finansial untuk membuat, memindahkan dan menjualnya. Dari sinilah, ide tentang hak kekayaan intelektual lahir. Ia datang bersamaan dengan hitung-menghitung biaya distribusi informasi, angka-angka biaya untuk menutup ongkos produksi, dan fee untuk menjual artefak fisik yang mengandung informasi.

Moralitas ekonomi yang lahir dari teknologi percetakan ini dapat dimaklumi karena belum ada banyak alternatif. Di samping itu, logika distribusi terbatas pasti mengakibatkan eksklusifitas atas beberapa orang yang menguasai informasi. Informasi dengan segera tersentralisasi kepada beberapa aktor, dan akan dianggap sebagai salah satu bentuk properti yang dihargai secara komersial. Oleh karena penghargaan atas informasi sebagai properti, maka sang pencipta informasi harus turut menikmati imbal hasil dari properti yang sudah dibeli dan dimanfaatkan.

Maka, begitu riwayat sentralisme ini dihapus oleh desentralisasi yang dibawa oleh teknologi internet, apa yang diakui sebagai properti informasi dan lazim diperjual-belikan, luluh lantak oleh segala situs-situs berbagi yang luar biasa banyaknya. Problem teoretik pun bergeser, dari "siapa yang berhak memutuskan konten media?" menjadi "apa saja yang akan dibagi?" Problem atas authority yang ada dalam logika sentralisme, tidak lagi menjadi penting di mata logika desentralisasi.

Dalam layanan sentralistis, preferensi konten dibuat dan didesain oleh operator, yang secara sekaligus pula mengambil peran sebagai "gatekeeper" seperti editor koran yang memutuskan mana berita layak muat, penerbitan yang memutuskan naskah mana yang ideal untuk mencetak buku, eksekutif TV dan radio yang memutuskan mana program yang layak mengudara, dan sejenisnya. Model gatekeeper ini kontras dengan model desentralisasi, di mana pengguna sendirilah yang memutuskan apa informasi yang dibagi atau dibuat, dan dengan demikian, apa pula informasi untuk dikonsumsi.

Desentralisasi jaringan, pun, secara teknis membawa serta desentralisasi kuasa. Ini karena telah terjadi pergeseran atas kewenangan individual dalam mengelola komunikasi, lalu-lintasnya, maupun produksi, distribusi, dan konsumsi pesannya. Ada sekurangnya dua alasan teknis dari pergeseran kuasa ini. Pertama, pengguna dapat membangun dan memulai server pribadi. Pengguna mampu mengelola dan mengautentifikasi diri ke server pribadi, menggunakan kode pribadi atau password, pengenalan suara, scan iris mata, atau apa pun yang pengguna suka. Hal semacam ini sama sekali tidak masalah karena pengguna tidak perlu bergantung secara fisik ke server lain. Kedua, dari server pribadi itu, dapat diciptakan aplikasi yang ingin dibuat atau digunakan. Server pribadi mengirimkan pesan, yang merupakan permintaan untuk sesi aplikasi, ke server aplikasi (Kumar, Jasmine \& Andrew: 2006).

Dalam isu yang paling baru, negara merasa kesulitan mengatur soal ini. UU Pemilu dapat dinukil sebagai contoh yang baik. Kendati UU Pemilu Nomor 8 tahun 2012 ini tegas-tegas mengatur metode kampanye, termasuk batasan hingga sanksi pelanggarannya, namun peraturan ini masih meninggalkan lubang menganga: seluruh pasal dalam bab VIII tentang kampanye sama sekali alpa merespons tumbuh kembang internet sebagai media baru arus utama. 
Contoh pemilukada DKI Jakarta 2012 lalu memang terlampau parsial untuk diambil, tetapi dari sini saja sudah dapat diraba kekosongan etika dalam memoderasi kampanye politik di ranah maya. Tidak ada satu pun pegangan normatif yang mampu mengantisipasi anomie lalu lintas pesan politik di internet. Akibatnya, jadwal kampanye mudah dilanggar, eksploitasi SARA merebak luar biasa, caci-maki menjadi strategi yang lazim, dan kampanye hitam dibiarkan.

Mendesaknya pengaturan atas kampanye politik secara online didasari dua sebab penting. Pertama, telah terjadi perluasan dan sofistikasi konteks politik. Kini tak lagi dapat ditentukan bahwa konteks riil politik adalah satu-satunya yang genuine dalam realitas politik, karena teknologi internet telah menciptakan arena realitas politik virtual yang jauh lebih luas dan tak terbatas. Maka, seiring ekspansi jangkauan konteks politik ke ranah virtual, itu berarti perluasan jangkauan etika juga harus diadopsi ke dalam internet.

Kedua, pada saat bersamaan simbiosis mutual antara jagad politik dan internet membuat keduanya saling membutuhkan satu sama lain, kendati dalam banyak hal juga menciptakan tegangan-tegangan di antaranya. Masuknya internet sebagai bagian penting dari metode kampanye dan debat politik telah membuat siapapun untuk memikirkan strategi etik guna memoderasi lalu lintas pesan online.

Lagipula, terhadap tumbuhkembang dinamika internet ini, dunia politik mau tak mau harus melakukan penyesuaian posisi. Sebab, model teknologi media baru adalah model di mana suatu keahlian teknis dari produksi dan konsumsi informasi politik dapat sepenuhnya didistribusikan secara swakelola kepada masing-masing individu pengguna media. Dalam logika seperti ini, tidak ada "pusat" yang membatasi atau mendikte. Tiap orang tak hanya memiliki kesamaan dalam hal membaca pesan atau informasi politik, melainkan juga menciptakannya secara otonom.

Oleh karena itu, kebebasan berpolitik dalam pengertian konvensional mengalami pergeseran ekstrim tatkala perluasan konteks politik di ranah media baru diterima sebagai bagian dari kenyataan politik. Kebebasan diartikulasikan lewat meningkatnya aksireaksi atas tiap-tiap peristiwa politik. Di dalam kebebasan itu, kesopan-santunan dan basa-basi politik yang acapkali mewarnai televisi dan surat kabar juga dapat didekonstruksi lewat olok-olok dan komedi satire.

Kini, seiring berjalan waktu, lambat laun mulai terjadi integrasi pengalaman politik yang berkait-kelindan dengan pengalaman kebebasan internet. Menguatnya kesadaran publik atas fasilitas internet yang menyediakan privelese politik, menjadi tantangan yang sukar dijawab, terutama lantaran risiko anarki pesan dan pendangkalannya.

\section{Desentralisasi \& Resistensi Etis: Online Hacktivism}

Dalam buku Cyber Citizenship and Cyber Safety: Cyber Ethics, Diane Bailey menjelaskan bahwa etika, "adalah aturan yang memandu untuk menentukan apa yang benar dan keliru, bahkan dalam situasi yang paling sulit dan dilematis sekalipun". Bertindak secara etis berarti melakukan hal yang benar walau terkadang dalam situasi yang sulit, dengan dibatasi oleh konteks ruang dan waktu dimana suatu tindakan itu terjadi. Jelas bahwa dalam realitas riil, konteks itu mewujud pada peraturan etis dari kebudayaan, kode etik profesi, 
atau peraturan etis yang disahkan negara. Kesemuanya ingin meringkas satu tugas besar: mengarahkan individu pada tindakan benar yang sesuai dengan budaya dan kebiasaan masyarakat umum di sekitarnya (Alfred: 2002).

Karena perluasan dan pendalaman atas jaringan konteks dimungkinkan seiring dengan perkembangan teknologi media, perluasan jangkauan etika juga diadopsi ke dalam dunia siber yang kita kenal dengan istilah Cyber Ethic atau etika siber. Menurut Richard A. Spinello (2004), cyberethics can be defined as the field of applied ethics than examines moral, legal, and social issues in the development and use of cybertechnology. Cybertechnology, in turn, refers to abroud spectrum of technologies that range from stnad alone, computer to the cluster of networked computing, information, and communication technologies. Spinello menyatakan moral, hukum dan isu sosial yang berkembang di dalam teknologi siber (cybertechnology), adalah substansi dari cyberethics.

Jika secara lentur teknologi siber dapat didefinisikan sebagai spektrum besar yang membahas tentang komputasi jaringan, informasi dan teknologi komunikasi, maka cyberethics sesungguhnya adalah etika dalam mengoperasikan jaringan internet, utamanya perilaku para pengguna.

Sederhananya, etika siber atau cyber ethics dapat dikatakan sebagai kumpulan nilai moral yang berkaitan dengan interaksi antar pengguna teknologi informasi. Belum adanya batas jelas dalam regulasi pemerintah dan ikatan etika yang diatur secara nyata dan luas di kalangan masyarakat dan para pengguna dunia siber, membuat setiap orang yang menggunakan teknologi informasi enggan mendengar, apalagi mematuhi, jargon-jargon etis. Sehingga saat bicara mengenai etika siber, maka tak ada istilah yang bertindak sebagai pengatur dan tak ada pula yang berposisi sebagai yang diatur. Dimensi subjekobjek ditinggalkan oleh karena tak ada peninjau atau pengawas etika - sesuatu yang boleh jadi sangat normal ditemui dalam lingkup riil (Caldow, 2004).

Longgarnya etika ditambah keyakinan bahwamengaturinternetadalahsiasia, telah menciptakan lubang menganga dalam konstruksi ruang publik dalam internet. Marwick (2008) membahas khusus tema internet dan politik. Internet menjadi obyek studi filsafat politik karena dua perkara mendasar. Pertama, internet berevolusi menjadi instrumen penting dalam upaya penguasaan politik. Kedua, dan oleh karenanya, internet digunakan dalam dialog politik antara politisi dan warga (citizen), bagi organisasi politik dan aktivis, untuk kepentingan pemilihan umum, diskusi politik bahkan aktivitas terorisme.

Sebuah filosofi politik negara modern yang tidak memperhitungkan keberadaan cyberpolitics akan berisiko terjebak hanya pada konsepsi usang dari proses politik. Selain itu, cyberpolitics sendiri adalah obyek yang layak studi, karena pertanyaan-pertanyaan tentang legitimasi politik dapat diajukan mengenai cara cyberpolitics seharusnya diselenggarakan. Di samping itu, internet seharusnya dipelajari oleh filsafat politik karena munculnya komunitas virtual dan jaringan sosial di dunia maya. Strukturstruktur sosial yang telah muncul di dunia maya, tampaknya tidak tunduk pada otoritas politik dari setiap bangsa konglomerat negara, sehingga sering disebut pula sebagai "masyarakat tanpa negara" (Winder, 2005).

Dalam konteks itu masyarakat tanpa negara ini, suatu resistensi atas semua peraturan etis dari bermacam-maca versi, muncul ke permukaan dalam bentuk 
yang sebelumnya sama sekali tidak terduga: hacktivism. Hacktivism secara definisi dimaknai sebagai aksi yang tidak menggunakan kekerasan fisik dan tidak menimbulkan kekerasan fisik secara langsung, melainkan melukai target lewat teknik hacking komputer untuk tujuantujuan politis. Bentuk aksi Hacktivism misalnya seperti yang dilakukan kelompok Hacktivism pertama the Cult of the Dead Cow di Amerika, salah satunya lewat aksi 'Goolag Tool' sebagai bentuk protes atas dominasi microsoft, kelompok Anonymous yang menyerang website Israel sebagai bentuk protes atas invasi perang Israel-Palestina atau kelompok The Electrohippies di Inggris dengan gerakan propaganda anti-globalisasi di dunia maya (Marwick, 2008).

Pelanggaran berat etika dunia maya-penggunaan identitas anonim/ palsu, menyerang data pribadi, pencurian perangkatlunak-dilakukanuntuktujuan advokasi politik. Seorang hacktivist tidak melakukan aksi (sekalipun ilegal) untuk tujuan profit atau menciderai internet users atau individu dan kelompok di dunia nyata. Diantara aksi-aksi Hacktivism yang dikenal umum oleh masyarakat global adalah DDoS Attack, Political Defacement/Cracking, penyerangan email, Hacking and Computer Breaks-in, serta penyebaran virus komputer dan worm (I LOVE U Virus) (Marwick: 2008).

Tanggal penting pertama dalam asal-usul hactivism dapat ditelusuri sejak tanggal 12 September 1981, ketika Chaos Computer Club, salah satu organisasi terbesar di dunia hacking, resmi dibentuk di Berlin. Sejak itu, jumlah pendukung hacktivism terus tumbuh sebagai kelompok yang bergabung secara digital guna mempromosikan perubahan politik dan sosial. Setelah mendapatkan perhatian luas dan ketenaran pada kuartal terakhir 2010, gerakan Anonymous merupakan komponen terbesar dan menjadi lambang gerakan hacktivisme kontemporer (Marwick, 2008).

Aksi kelompok Anonymous yang paling terbaru adalah menyerang sistem keamanan jurnal berbayar JSTOR, dan memublikasikan ribuan artikel berbayar tersebut ke situs-situs berbagi. Aksi ini ditujukan untuk menyindir korporasi yang memperjual-belikan pengetahuan, sumber keilmuan, secara sangat mahal dan tidak terjangkau.

\section{Pukulan Balik: Sentralisasi Negara \& Korporasi}

Upaya desentralisasi jaringan telah mengubah keseimbangan kekuasaan politik. Namun demikian, bentuk teknologi komunikasi jaringan sosial saat ini, meskipun memiliki nilai yang sangat besar untuk dimanfaatkan sebagai kekuatan dan konsolidasi politik, juga sangat berisiko mengalami pukulan balik. Sistem desentralisasi yang ada saat ini, dalam beberapa hal memiliki celah dan terpusat, dalam beberapa aspek masih tampak sentralistis; mereka terlalu rentan terhadap pembalasan dan kontrol negara.

Bukti paling telak dalam pendapat penulis ini adalah diluncurkannya perundangan Stop Online Piracy Act (SOPA) dan Protect IP Act (PIPA), yang menghajar seluruh situs penyedia layanan berbagi (file sharing) di Amerika Serikat. Meskipun komunitas internet dunia tetap memberikan resistensinya atas peraturan ini, toh itu tidak mengubah kondisi bahwa sistem yang terdesentralisasi ini, masih terlalu rentan karena negara masih memiliki kewenangan dan cara untuk mengontrolnya.

Negara dapat mendesain skema kebijakan guna mengontrol konten. Salah satu teknik kontrol atas suatu jaringan, adalah selalu melibatkan jaringan lain untuk melakukan fungsi represif, yakni 
jaringan situs pemblokir (Oates: 2006). Sementara itu, beberapa kelompok sedang mengembangkan mekanisme untuk mengalahkan taktik pemerintah. Kontestasi ini menyerupai logika kucingdan-tikus, di mana satu sama lain samasama berupaya merebut tempat paling menguntungkan dari kebijakan yang ada.

Selain peranan negara dalam mendisiplinkan dan mengerkah batang leher desentralisasi internet, korporasi juga memiliki kesempatan dan peluang yang sama dalam mengontrol jejaring internet. Sejak bulan Januari 2011, konsorsium investor telah menempatkan modal sekitar \$ 50 miliar pada Facebook, jaringan sosial yang didirikan oleh Mark Zuckerberg (NYT, 2011). Jika revolusi dunia bersandar pada situs-situs semacam Facebook, maka persoalan yang akan muncul bukan hanya kebutuhan kaum revolusioner untuk menjaga agar Zuckerberg dan korporasi Facebook untuk tetap loyal, melainkan juga harus mengendalikan individu yang memiliki saham besar dalam korporasi itu. Sebab, ketika semua orang hanya bergantung dalam satu database besar yang dikendalikan oleh Zuckerberg, adalah hal yang amat mudah untuk menjegal revolusi hanya dengan mengirimkan perintah dan tawaran yang tak dapat ditolak kepada pihak korporasi.

Lewat trik penyensoran yang paling mudah, perusahaan/korporasi dapat dengan sangat ringan mengubah kebijakannya agar tak terlalu permisif. Korporasi dapat mengondisikan peraturan sehingga ia mengikat pengguna dengan peraturan itu, dan memaksa user untuk melakukan swa-sensor atas semua aktifitasnya di jaringan. Strategi ini dapat diiringi dengan mengancam dihapusnya akun-sebuah penanda eksistensi user atas identitasnya. Sementara itu, perlawanan atas situasi ini bisa diakali dengan terus berpindah-pindah dari satu penyedia hosting ke penyedia yang lain, selama pengguna mampu mengendalikan domainnya sendiri.

Maka, di sini terjadi tolak-tarik yang sama kuatnya. Pada satu sisi, dengan puluhan ribu server yang dienkripsi oleh individu-per-individu, tidak akan ada satu tempat di mana pemerintah represif bisa mencari tahu siapa yang menerbitkan atau membaca materi subversif itu. Akan tetapi di sisi lain, negara dapat menerbitkan peraturan, dan korporasi beserta konsorsium industri internet tetap bisa mengontrol semua konten dalam situsnya.

Penting pula diingat, pemerintah sebetulnya sudah bersiap dalam menyambut gelombang besar demokrasi a la online ini. Usaha untuk mendorong seluruh instansi negara agar memiliki forum dan website sendiri, adalah salah satu upaya yang patut dihargai, kendati perkembangannya masih jauh dari harapan. Negara berupaya merespons pertumbuhan signifikan teknologi informasi. Sejak tahun 2008, tanda-tanda menguatnya adopsi teknologi sudah dapat dilihat sebagai perkembangan yang terlampau pesat. Pada tahun itu, pertumbuhan telepon seluler mengalami pertumbuhan paling tajam. Tahun 2007 pemilik telepon seluler 93,39 juta $(41,35 \%)$, tahun 2008 mencapai angka 124,81 juta (54,61\%). Awal mula menajamnya pertumbuhan ini adalah sangat penting karena berhubungan langsung pula dengan pertumbuhan akses atas informasi.

Selain itu, peningkatan tersebut juga didorong oleh semakin turunnya tarif internet di Indonesia. Pertumbuhan TIK dan penurunan tarif internet ini berdampak positif kepada masyarakat sebagai pengguna internet. Berdasarkan laporan Internet World Stats, pengguna 
internet di Indonesia semakin berkembang mencapai $10,50 \%$ dari jumlah penduduk Indonesia, meskipun masih di bawah negara tetangga. Seperti Malaysia $(62,80 \%)$, Singapura $(67,40 \%)$, Thailand (20,50\%), Filipina $(14,60 \%)$, dan Brunei Darussalam (46,20\%) (Internet World Stats: 2011).

Fenomena di atas direspons secara beramai-ramai bukan hanya oleh lembaga-lembaga negara (eksekutif, yudikatif dan legislatif), melainkan juga oleh partai-partai politik untuk penetrasi informasi politik sekaligus membuka peluang kepada masyarakat untuk berinteraksi dengan lembaga-lembaga pemerintah melalui web site yang mereka bangun. Kalaun ingin berprasangka baik, kondisi ini membantu peningkatan legitimasi lembaga-lembaga pemerintah dan partai politik; tetapi juga, prasangka buruknya, berisiko mencemari dinamika ruang diskusi maya dengan segala teknik pencitraan dan penetrasi politik.

Negara bahkan lebih jauh membuat Instruksi Presiden RI Nomor 6 Tahun 2001 tentang Inisiatif e-Government dan dipertegas dengan Instruksi Presiden RI Nomor 3 Tahun 2003. Tindak lanjut dari kedua instruksi presiden tersebut adalah masing-masing daerah tingkat 1 dan 2 telah membangun website sebagai respon sekaligus langkah awal dari instruksi presiden tersebut.

\section{Daftar Pustaka}

Ahn, Yong-Yeol. Han, S., Kwak,. H., Moon, S. (2011) Huge Online Social Networking. London, Routledge.

Barabasi, Albert-Laszlo., Albert., Reka. (1999). Emergence of Scaling In Random Networks. Science, 286

Baran, Paul. (1964), On Distributed
Communications:
to Distributed

Networks. Santa Monica: The Rand Corporation

Berlo, David K., (1960). The Process of Communication, New York: Holt, Rinehart, and Winston

Cardoso, Gustavo. (2006). The Media in the Network Society: Browsing, News, Filters and Citizenship, Lisboa, Portugal. CIES - Centre for Research and Studies in Sociology.

Donath, J., Boyd, D. (2004). Public Displays of Connection. BT Technology Journal, 22(4)

Foucault, Michel. [1976] (1998). The History of Sexuality Vol. 1: The Will to Knowledge. London: Penguin.

Goldsmith, Jack. \& Wu, Tim. (2006). Who Controls The Internet? Illusions of a Borderless World, New York, Oxford University Press

Kompas, 8 Oktober 2012

Kumar, Ravi., Novak, Jasmine., Tomkins, Andrew. (2006). Structure and Evolution of Online Social Networks. In Proc. Of KDD, pages 611-617.

Morland, Mollie. (2005). Redefining Accountability in a Network Society, Santa Clara.

Poplawski, Laura J. (2008). Bounded Budget Connection (BBC) Games or How to Make Friends and Influence People, on a Budget, PODC

Oates, Sarah. Owen, Diana. \&.Gibson, Rachel K. (ed), (2006). The Internet and Politics; Citizens, Voters and Activists, London, Routledge.

Rogers, Everett M., Kincaid, D. Lawrence. (1981). Communication Networks: Toward a New Paradigm for Research, Free Press (New York and London).

Shannon, Claude E., Weaver, Warren. (1964). The Mathematical Theory of Communication, The University Of Illinois Press Urbana

The New York Times, 2011/02/16/ 